\title{
TELEOWITALIZM MITYCZNY CZY UTOPIJNA AFAZJA? O WYSPIE LEOPOLDA STAFFA
}

\author{
KRZYSZTOF M. MAJ* \\ Znacie przestrach w chwili zasypiania? Aż po palce stóp przeraża się zasypiający, \\ iż ziemia usuwa się przed nim, a sen się poczyna ${ }^{1}$.
} Friedrich Nietzsche

Wyspa jest najnaturalniejszym z symboli. Leżąc u zbiegu literackiego horyzontu i historycznej perspektywy, ewokuje niezwykłą mnogość znaczeń, rozpraszających zaległe nad okalającymi ją wodami mgły niezrozumienia, lęku i wątpliwości. Służy za erem anachorecie, za schronienie rozbitkowi, za dominium wygnańcowi, za więzienie tyranowi, za cel żeglarzowi, za ideał utopiście. Jest morskim solitudo, cichą proklamacją milczenia i samotności - a niekiedy jedynie wyrazem twórczej imaginacji, będąc surogatem nieziszczonych dążeń, niespełnionych marzeń i niezrealizowanych celów. Tak oto w zmetaforyzowanym ujęciu przejawia się polisemiczność wyspy, utrwalonej w świadomości kulturowo-literackiej Śródziemnomorza jako (w szerszym sensie) symbol niestałości, sytuujący się w opozycji wobec kojarzonego ze stabilnością i trwałością kontynentu, a niekiedy, przeciwnie, jako raj ziemski, swoisty „,punkt metafizycznej mocy, w którym skupiają się siły bezbrzeżnej nierozumności oceanu" ". Jest więc wyspa bądź urzeczywistnieniem piękna najdoskonalszego, harmonii i wiekuistej szczęśliwości - jak w toposie wysp błogosławionych i Elizjum³ - bądź też jego aberracją

* Krzysztof M. Maj - student Wydziału Polonistyki Uniwersytetu Jagiellońskiego.

${ }^{1}$ F. Ni et z s c he, Tako rzecze Zaratustra. Ksiqżka dla wszystkich i dla nikogo, przeł. W. Berent, Kęty 2004, cz. II, rozdz. XXII: W najcichszq godzinę, s. 105.

2 J. E. Cirlot, Wyspa [w i de m:] Słownik symboli, przeł. I. Kania, Kraków 2006, s. 465. Cirlot - o czym warto nadmienić - odwołuje się w tym samym miejscu również do teorii psychoanalitycznej Carla Gustava Junga, wedle którego wyspa miała być „schronieniem przed groźnym atakiem morza nieświadomego, tj. syntezą świadomości i woli” - schronieniem skądinąd jakże bliskim utopizmowi.

${ }^{3}$ Pierwszy obraz wysp błogosławionych odmalowuje Hezjod w słynnych Operae et diei:

Tam teraz żyją spokojnie nie znając kłopotów ni troski

Bohaterowie szczęśliwi na wyspach szczęśliwych, gdzie boski

Szumi Ocean w głębinach. A ziemi rodzajnej zagony

Trzykroć w roku im dają obfite i słodkie swe plony.

(BN II 71, przeł. W. Steffen, Wrocław 1952, ww. 170-173) 
- jak w przypadku krain zmarłych czy też tzw. wyspy przeklętej ${ }^{4}$ - lub wreszcie celem voyages imaginaires, literackich peregrynacji ku wyimaginowanym światom $^{5}$. We wszystkich tych wypadkach pomiędzy imaginarium - bez względu na jego pozytywne bądź pejoratywne nacechowanie - a światem realnym wytwarza się szczególny rodzaj relacji, reorientującej i przewartościowującej bohatera literackiego względem rzeczywistości przedstawianej. Relacji, której dominantą staje się akt upodmiotowienia poznania.

Poemat Wyspa Leopolda Staffa, pochodzący z tomu Ptakom niebieskim (1905), wyzyskuje aż dwie spośród trzech możliwych depikcji motywu, a mianowicie topos wyspy szczęśliwej oraz konwencję voyage imaginaire, dopełnione swoistymi dla ówczesnego okresu poezji staffowskiej ${ }^{6}$ konstantami snu (marzenia sennego), wędrówki, idealizmu, witalizmu oraz nietzscheanizmu ${ }^{7}$. Poemat to, najkrócej mówiąc, o akcie zapośredniczenia (Vermittlung) ${ }^{8}$ celu, dokonywanego przez podmiot uwikłany - tak świadomie, jak i nie - w konfrontację pomiędzy światem codziennych doświadczeń a dziedziną Rajskiej ułudy:

\section{Dom mój na brzegu stał hucznego morza, \\ Patrząc swych okien bezsennych tęsknotą \\ Na toń błękitną i modrą i złotą, \\ Która w bezbrzeżne toczy się bezdroża9 .}

jednakże, jak odnotowuje Jerzy Kwiatkowski, topos ten pojawia się nie tylko w mitografii grecko-rzymskiej, ale także w indyjskiej (Wyspa Klejnotów), babilońskiej czy celtyckiej (wyspa Avallon). Zob. J. K w i atk ow s ki, Raj utracony [w:] U podstaw liryki Leopolda Staffa, Warszawa 1966.

${ }^{4}$ J. E. Cirlot, Wyspa przeklęta [w:] op. cit.

${ }^{5}$ Konwencja voyages imaginaires, rozwinięta w literaturze prozatorskiej europejskiego Oświecenia (Przypadki Robinsona Crusoe Daniela Def oe, Podróże do wielu odległych narodów świata Jonathana S w if t a, Podróż do krajów podziemnych Mikołaja Klimiusza Ludwiga Hol ber g a, Mikołaja Doświadczyńskiego przypadki Ignacego Krasicki e go, Wojciech Zdarzyński życie i przypadki swoje opisujacy Michała Dymitra Krajew skie go, Kandyd czyli optymizm Volt ai re'a, Rok 2440 Louis-Sébastien Mercie ra etc. al.), jakkolwiek wiązała się z literaturą utopijną oraz dystopijną, miała swe antecedencje jeszcze w literaturze średniowiecznej (Podróż św. Brendana) czy wczesnonowożytnej, zawierającej opisy dziwacznych krain „opilstwa i oźralstwa” (fr. Le Pays de Cocaigne, niem. Schlaraffenlanden; w literaturze polskiej - np. w Królu w kraju rozkoszy Franciszka Za bło c ki e go można spotkać formę spolszczoną - Kokania). Ciekawy w tym kontekście jest również topos Narrenschiff, statku głupców wypływającego do krainy wiecznej szczęśliwości (Stultifera navis Sebastiana B ranta), emulowany groteskowo przez François Rabe la is' go na kartach Gargantui i Pantagruela w opisie wyspy płaskonosów.

${ }^{6}$ Na potrzeby niniejszego wywodu przyjęto periodyzację Sandauera. Por. A. S a n d a u e r, Leopold Staff [w:] Poeci trzech pokoleń, Warszawa 1955, s. 9-14, zwłaszcza zaś s. 23.

7 Właściwymi skądinąd dla większości utworów z tego tomu, ex.g.: Pogoda, O radosnej ojczyźnie, Odkrywca złotych światów, O zbawczej ułudzie, Gość, Otchłań kuszqca czy O sprzyjanie nieznajacym cnoty.

${ }^{8}$ Posługuję się niniejszym terminem w znaczeniu Fichteańsko-Heglowskim, a więc przeciwstawiającym - w ogólniejszym sensie - doświadczenie bezpośrednie doświadczeniu zapośredniczonemu.

${ }^{9}$ Cytaty z Wyspy pochodzą z wydania: L. St aff, Ptakom niebieskim, Lwów 1905. 
Ów sugestywny obraz poetycki niesie ze sobą niezwykle istotne waloryzacje aksjologiczne: oto bezruch („dom [...] stał”), stałość i bezpieczeństwo („,dom mój”) oraz związany z nimi dyskomfort psychiczny (kunsztowna hypallage „okien bezsennych”) poddane zostają deprecjacji na rzecz aprecjacyjnego ukazania piękna bezkresu (potęgujący to wrażenie polisyndeton „toń błękitna i modra i złota”), dynamiki (,toń [...] toczy się") i majaczącej na horyzoncie obietnicy nieskończoności (aliteracyjnie zestawione „,bezbrzeżne [...] bezdroża”). W konsekwencji już od pierwszej części poematu towarzyszy odbiorcy świadomość istnienia wywołujących wewnętrzne napięcia poetyckich kontradykcji, w wyniku których doczesna tęskna bezsenność zostaje przeciwstawiona pokusie śnienia:

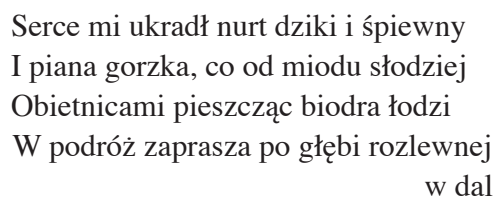

Aluzję do zawartego w XII księdze Odysei pamiętnego opisu kuszenia Ulissesa przez syreny ${ }^{10}$ wprowadził Staff z wyjątkową maestrią: zarówno bowiem statkowi, jak i wodom morskim naddane zostały żeńskie atrybuty (,,biodra łodzi” czy „nurt śpiewny” ${ }^{11}$ ), dopełnione nadto wyzyskaniem skonwencjonalizowanego słownictwa poezji miłosnej, wywodzącego się jeszcze ze średniowiecznej poezji prowansalskiej z kręgu amour courtois (serce, gorycz, słodycz, miód, obietnica, pieszczota). Ta nieprzypadkowa erotyzacja opisu wyraźnie potęguje napięcie pomiędzy domeną niespełnionej tęsknoty, loco horribile podmiotu lirycznego, a miejscem jego nieziszczonych pragnień - loco amœenum. Bez radykalizacji opozycji i przewartościowania wartości nie byłoby bowiem w ogóle owego uczucia dojmującej tęsknoty, będącego emocjonalnym imperatywem całego poematu. Władysław Madyda imperatyw ów zrównał ze swoiście pojętym daimonionem, niebędącym głosem rozumu, lecz jedynie ,głosem wrażliwości na życie jako przedmiot przeżycia poetyckiego, który w równej mierze czerpie ze świata rzeczywistości, jak i złudy"12. Z porządku nierzeczywistego czerpie więc Staff czystość sennego marzenia, z porządku rzeczywistego zaś - piękno nawracającej tęsknoty:

\footnotetext{
Wyspa! A ja tu leżę nieruchomy

Na brzegu, łodzi nie mając ni żagli,

Które wichr słony do pośpiechu nagli

Na wód szaleństwa i swobód ogromy.
}

${ }^{10}$ Ho mer, Odyseja, przeł. L. Siemieński, BN II 21, Kraków 1922, ks. XII, ww. 166-183.

${ }^{11}$ Co notabene odpowiadałoby wysuniętej przez Cirlota hipotezie semiotycznej relewancji wyspy i kobiety. Por. J. E. Cirlot, Wyspa [w:] loc. cit.

${ }_{12}$ Por. W. Mad y da, Motywy antyczne w poez.ji Leopolda Staffa, Wrocław 1962, s. 77. 
I jeno tęsknię, marzę, śnię mamidła [podkr. - KMM]

Na brzegu siedząc - już nie wracam do dom

Na pastwę swoim pragnieniom i głodom,

Bo dom mi obrzydł i izba mi zbrzydła!

Gwałtowna pointa, dla uzyskania większej wyrazistości ujęta w paralelę (na granicy hemistychów: „bo dom mi obrzydł” + „,izba mi zbrzydła”), zaskakuje wobec zwiewnej metaforyki strof ją poprzedzających siłą ekspresji, zbliżając się w swej formie do znanych z poezji modernistycznej postaw buntu wobec świata ze wszystkimi jego ograniczeniami społecznymi, moralnymi i intelektualnymi ${ }^{13}$. Poza szaleństwa, zachłyśnięcia witalistycznym zachwytem, już przez Artura Sandauera rozpoznana jako differentia specifica wczesnego okresu twórczości Leopolda Staffa ${ }^{14}$, zyskuje w Wyspie wymiar bodaj najpełniejszy ${ }^{15}$. Ślepy zachwyt ,złotym sercem oceanu” i dionizyjski taniec duszy stają się tu jedynym prawem, wykraczającym poza ograniczenia chłodnego racjonalizmu i wyrywającym z okowów ziemskiej doczesności:

Czy skwar mnie pali czy noc chłodem ziębi

Po fali puszczam wzrok zachwytem ślepy

A gdy się znużę, patrzę w niebios sklepy,

Lecz dusza tańczy, jak połysk po głębi.

Na wznak na brzegu leżę rozciągnięty

I piję niebios błękitną truciznę,

Kojący obłęd, który snu w ojczyznę

Majaczeń wiedzie, jak w przystań okręty

Metaforyczne spijanie z niebios „błękitnej trucizny” oraz oksymorony ,ślepy wzrok” czy „kojący obłęd” naprowadzają na trop, iż podobnie jak w początkowych strofach poematu Staffa tradycyjne siatki skojarzeniowe podlegały całkowitej reorientacji, tak i tutaj osiągnięcie upragnionego stanu sacrosanctum ${ }^{16}$ wymagać będzie od podmiotu lirycznego najradykalniejszych nawet przewartościowań. To dlatego właśnie jego celem najwyższym staje się odtąd przedzierzgnięcie snu zwykłego w somnambuliczną wędrówkę ku ideałowi metafizycznej

${ }^{13}$ Irena Maciejewska dostrzega tu wyraźne nawiązanie do Statku pijanego A. Ri imbauda. Patrz I. M a c i e je w sk a, Leopold Staff - lwowski okres twórczości, Warszawa 1965, s. 99.

${ }_{14}$ Por. A. S a nd a u e r, loc. cit.

15 Porównywalną może tylko ze słynnym Sonetem szalonym (Ptakom niebieskim, 1905):

Lekkomyślność śpi ze mną, płocha weselnica, Sakwę, gdziem mądrość chował, przedarła psotnica

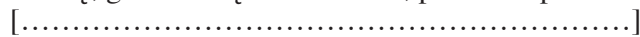

Proszę cię, duszo moja, bądź-że mi szaloną!

(Sonet szalony, PN)

${ }^{16}$ Określenie autorstwa samego Leopolda Staffa. Patrz L. Staff, Rekonwalescencja końca wieku [w:] Leopold Staff, red. I. Maciejewska, Warszawa 1965, s. 57. 
doskonałości, z którym pełne zjednoczenie jednakowoż wymagać będzie pewnej ofiary:

\author{
I nagle czuję, że brzeg się u r y w a [podkr. - KMM] \\ Pode mną... Ziemia mi spod nóg opada \\ I lecę w górę, nad obłoków stada... \\ W błękit mnie ciągną powietrzne ogniwa...
}

Oderwanie od rzeczywistości zostaje potraktowane przez Staffa z całą przysługującą frazeologii dosłownością i całą właściwą liryce umownością. Może być to bowiem zarówno symbol śmierci - fizycznej (osunięcie się brzegu i utonięcie w odmętach morskich) lub psychicznej (osiągnięcie punktu zwrotnego w świadomości) - jak również transpozycja obrazu wzlatujących „nad obłoków stada” volucres coeli na bezpośrednie doświadczenie transcendencji ${ }^{17}$. Najcenniejsze dla interpretacji byłoby jednak potraktowanie strofy tej jako projekcji nietzscheańskiego „strachu zasypiania”, lęku przed zstąpieniem w otchłań wymykającej się racjonalnym osądom podświadomości, momentu zarówno największej słabości, jak i największej siły jednostki ludzkiej. We wszystkich tych przypadkach, równocennych, jak się wydaje, dla interpretacji, najistotniejszy byłby aspekt zmiany wektoru oddziaływania otchłani ${ }^{18}$, tu wyniesionej do sfery sacrum, i kuszącej swym „bezdnem” aż do bezmiaru nieskończoności ${ }^{19}$ :

${ }^{17}$ Co wywoływałoby parantelę Staff-Verlaine. Patrz R. P a ty k, Szlakiem ptaków niebieskich, czyli „podróż szalona” Staffa. O „Odkrywcy złotych światów” [w:] Poezje Leopolda Staffa. Interpretacje, red. A. Czabanowska-Wróbel, P. Próchniak, M. Stala, Kraków 2005, s. 254-255.

${ }^{18}$ Hierofania otchłani stanie się zresztą w późniejszych od Wyspy utworach kolejnym ze swoistych dla Staffa motywów, powracając w cyklu Nokturny (Sowim piórem, 1921):

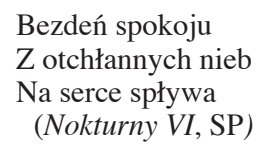

i osiągając apogeum wyrazu w sonecie Mój Bóg to przepaść (Ucho igielne, 1927):

Mój Bóg to przepaść! Mój Bóg to bezdno

(Mój Bóg to przepaść, UI)

Egzemplifikacja za: M. Podraza-Kwiatkowska, Potrójna teofania L. Staffa. O wierszach: Mój Bóg to przepaść, Noc, Zasłony [w:] Poezje..., op. cit., s. 8-11.

${ }_{19}$ Zarysowany kontekst wiktymologiczny pogłębia wiersz Otchłań kuszq̨ca (Ptakom niebieskim, 1905), będący sui generis poetycką odpowiedzią na znany apoftegmat nietzscheański o względności relacji człowiek-otchłań:

Długo siedzieliśmy w bezradnej męce,

Minęły pełnie księżyca i nowie -

Aż rzekł brat jeden: „Oto się poświęcę”...

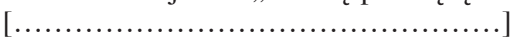

I jął posuwać się brat na kolanie

Nad brzeg przepaści... aż legł nad krawędzie

I spadł! pożarły go czarne otchłanie!

(Otchłań kuszqca, PN) 
Otchłań mnie pije... Z ciężkich snów bezsiły

Wstaję oparem wzwyż... Lekkość taneczna

W pląs mnie porywa, gdzie wyspa powietrzna

Płynie owiana świetlanemi pyły...

Spijanie otchłani, symbolizujące metafizyczne wypłynięcie na głębię, biblijne duc in altum ${ }^{20}$, wbrew pozorom nie wywołuje żadnej antynomii pomiędzy „niebios sklepy” a „głębią rozlewną". To raczej odwołanie do ukonstytuowanego już w kulturze i języku zwyczaju kontaminowania pól semantycznych żywiołu wody i nieba (np. prom kosmiczny, fale świetlne, strumienie fotonów itp.), umotywowanego tak podobieństwami czysto wizualnymi (kolor i wielkość), jak i zjawiskami natury optycznej ${ }^{21}$, i wywołującego wrażenie ontycznej jedni, spajającej pozorne przeciwieństwa i wynoszącej je ku najwyższej doskonałości. Przestwór staje się tu w konsekwencji ,pośrednikiem między człowiekiem a transcendencjąa" 22 , kosmosem, mediacją pomiędzy misterium tremendum a misterium fascinans, sferami, w których „obok elementu szału występuje element oczarowania, wprawienia w zachwyt" ${ }^{\prime 23}$. Stąd właśnie w cytowanej strofie pojawia się obraz bezbrzeżnego, mistycznego zachwytu, „lekkości tanecznej”, poprzedzającej fantastyczną wizję ziemskiego empireum:

Przystań błądząca, jak łódź bez przystani

Żegluje w zwiewnych mgłach, gdzie sny, jak ryby

Skrzące pozłotą łusk przez kryształ szyby

Świecą w przeźrocznej, niechwytnej otchłani.

Poderwany szałem uniesien staffowski latus et errabundus trafia do domeny ułudy, „przystani błądzącej”, nawiązującej swym metaforycznym mianem zarówno do motywu rycerza-pielgrzyma - chevalier errant ${ }^{24}$ - jak i do symboliki błędnych ogni (,sny, jak ryby, skrzące pozłotą łusk przez kryształ szyby”), wabiących swym złudnym światłem w głąb bagien i moczarów - ku „niechwytnej otchłani”.

${ }^{20}$ Warto w tym miejscu przypomnieć, iż łaciński rzeczownik altum tłumaczy się zarówno jako 'głębokość, głębinę, pełne morze', jak i ‘wysokość, to co znajduje się w górze', czy, co chyba najciekawsze, jako 'rzeczy ukryte, tajemne, głębię i otchłań'. Por. Słownik łacińsko-polski, red. M. Plezia, t. I, Warszawa 1959, s. 160.

${ }^{21}$ Maria Podraza-Kwiatkowska zauważa, iż grze wektorami (góra-dół) sprzyja efekt lustrzanego odbicia (tutaj w tafli okalających wyspę wód). Patrz M. Podraza-Kwiatkow ska, op. cit., s. 11.

${ }^{22}$ Cyt. za: ibidem, s. 14.

${ }^{23}$ R. Otto, Świętość. Elementy irracjonalne w pojęciu bóstwa i ich stosunek do elementów racjonalnych, Wrocław 1993, s. 59. Cyt za: ibidem, s. 8.

${ }^{24} \mathrm{~W}$ jednym z nowszych opracowań motywu Joanna Gorecka-Kalita zauważa, że francuskie errar wywodzi się nie od łac. erro, errare (błądzić), lecz itero, iterare (wędrować), co sprawia, iż chevalier errant jest raczej pielgrzymem, aniżeli snującym się bez celu „błędnym rycerzem”. Por. J. Gorecka-Kalit a, Trzy materie narracyjne i rozwój powieści dwornej [w:] Tristan i Izolda, BN II 254, Wrocław 2006. 
Otchłań ta wszelako zostaje ostatecznie wyzuta (chociażby poprzez zestawienie z kojarzoną pozytywnie przystanią) z wszelkich negatywnych konotacji ${ }^{25}$, zespajając się z konwencjonalną topiką loci amoni, wykorzystaną do wypełniającego kolejne dwie strofy synestezyjnego opisu ,wyspy-tajemnicy”:

\footnotetext{
Drzewa tam rosną, płynne jako rzeki...

Z źródeł korzeni szmaragdami cieką

Fale ich liści, w lasy mórz, daleko.

A wstęgi woni płyną z ziół w pasieki,

Płyną w ul słońca miodnemi strunami.

A rzeki kwitną w szklane wodne drzewa

Roniąc liść, który śpiewa, jak ulewa,

I rosną w niebo swych strug gałęziami
}

Właściwe sferze empireum ogień i światłość, tak wspaniale wpisujące się w znaną z twórczości Staffa paletę złocieni ${ }^{26}$, znamionują mityzację opisu, odwołując się do ukonstytuowanej w tradycji literackiej wizji wysp szczęśliwych, skąpanych zawsze w blasku słońca (zgodnie z tradycją platońską i postplatońską utożsamianego z ideą najwyższego dobra) i tętniących bujnym, rozkwitającym życiem. Trop ten potwierdza sugestywna metonimia „szmaragdami cieką fale”, które wraz z powracającym w dalszych częściach poematu podobnym obrazowaniem („,wodny zielony klejnot”, „,bursztynowe lśnienie”, „szmaragd rzek”, ,groty z szafiru"), każe zastanowić się nad możliwością istnienia intertekstualnej więzi pomiędzy Staffowską wyspą a utrwaloną w mitologii hinduskiej wizją Wyspy Klejnotów (Manidvipa), będącej bliskowschodnim ekwiwalentem greckiego Elizjum. Kontekst ten dopełniłyby również pośrednie nawiązania do europejskiej utopistyki, z możliwymi aluzjami do Miasta Słońca Tommasa Campanelli czy Bajki o pszczołach (,ul słońca”) Bernarda de Mandeville'a na czele, wszelako są to odwołania na tyle odległe i trudne do jednoznacznego dowiedzenia, iż wspominać o nich należy wyłącznie dygresyjnie. Niemniej, z wszystkich tych sygnałów intertekstualnych wynikałoby, iż Staff kreuje obraz wyspy idealnej z dogłębną świadomością podejmowanej konwencji, nie przestając równocześnie przypominać o ulotnym charakterze fantazmatów utopijnych: warto zauważyć bowiem, iż panorama owej idealnej krainy jest w szczególny sposób dynamiczna (,,wstęgi woni płyną”, „, źródeł [...] cieką fale [...] liści”, ,rzeki kwitną w szklane wonne drzewa" i ,rosną w niebo strug swych gałęziami), przypominając zaiste świat widziany przez „kryształ szyby”, migoczący w oddali niczym zwodnicza fatamorgana. Czym jest zaś ruch, jeśli nie oznaką życia? Witalistyczny topos natura naturans lub wręcz natura devoran ${ }^{27}$, ewokowany w marzeniu sennym

\footnotetext{
${ }^{25}$ M. Podraza-Kwiatkowska, loc. cit.

${ }^{26}$ O frekwencji przymiotnika ,złoty” w poezji Staffa patrz R. Pat y k, op. cit., s. 263.

27 Sugestia interpretacyjna prof. Mariana Stali.
} 
podmiotu lirycznego, jest - paradoksalnie - wyrazem przepełniającej wyspiarskie życie celowości. Owa szczególna postać celowości uwidaczniałaby się w dezawuacji wyobrażenia o statyczności wszelkiej utopii: szczęście mianowicie, równie jak doskonałość, jest pojęciem teleologicznym, implikującym cel - a zatem skończonym (perfectus) jedynie pozornie, trwającym bowiem w wieczystym napięciu z przyszłym i założonym. Przeświadczenie to zyskało kształt wyrazisty już w słynnej definicji doskonałości autorstwa Dunsa Szkota, według którego byłaby ona pojęciem skończonym implikującym cel ostateczny (finis ad quem res principaliter ordinatur) ${ }^{28}$, ale jego prefiguracje kryła już Arystotelejska koncepcja entelechii jako aktu doskonałości tożsamego z działaniem ${ }^{29}$. Bez uświadomienia tych kontekstów filozoficznych nie sposób dogłębnie zrozumieć witalizmu Bergsona i jego élan vital, życiowego pędu nadającego cel istnieniu i będącego tym samym przejawem tętniącego radością życia ${ }^{30}$, niesytuującego się bynajmniej w proste opozycje w rodzaju statyczności i dynamiczności czy zamknięcia i otwarcia. A tymczasem właśnie ta długa tradycja filozoficzna leży u źródeł nietzscheańskiego teleowitalizmu, przez Jerzego Kwiatkowskiego uznanego za dominantę wczesnej filozofii poetyckiej Leopolda Staffa ${ }^{31}$, zaś w analizowanym poemacie pełniającego funkcję szczególną: decydującego bowiem w równej mierze o inkluzji, ontycznym ograniczeniu tytułowej wyspy, jak i o sile rozsadzającej ją żywotnej, witalistycznej energii ${ }^{32}$.

Lecz fala padła mi kropel rozpryskiem

Na oczy... Pierzchnął majak pełen blasku

Senny zbudziłem się na brzeżnym piasku,

Spętany dawnej niemocy uściskiem.

[oba podkr. - KMM]

${ }^{28}$ Pisał Duns Szkot: „Doskonałe jest to, co osiągnęło pełnię własności mu dostępnych. Toteż »cały $\mathrm{i}$ »doskonały « znaczą mniej więcej to samo »totum et perfectum sunt quasi idem «. Było to pojęcie teleologiczne: albowiem implikuje cel (»finis ad quem res principaliter ordinatur «)". Podaję za: W. Ta ta rki e w i c z, Doskonałość ontologiczna i teleologiczna, [w i d e m:] O doskonałości, Warszawa 1976, s. 62.

${ }^{29}$ „Celem bowiem jest działanie, a działanie jest aktem. I dlatego nazwa »akt« wywodzi się od działania i rozciąga na oznaczenie tego, co dokonane (gr. $\sigma v v \tau \varepsilon i v \varepsilon \iota \pi \varrho o ̀ \varsigma ~ \varsigma \eta ́ v ~ \varepsilon ́ v \tau \varepsilon \lambda \varepsilon ́ \chi \varepsilon \varepsilon \iota \alpha \nu$ [syntéinei pros ten entelécheian])". Ary st ote le s, Metafizyka, 1050 a 22. Warto w tym miejscu przypomnieć, iż bezokienne monady Leibniza pierwotnie również zwane były przezeń entelechiami.

${ }^{30}$ Powiada sam Staff: „Życie! Znaleźć upodobanie w życiu, nauczyć się je kochać, nauczyć się czuć jego rozkosze, jego piękno, to, co jest w nim dobre. Przestańmy być ascetami, ro zg ląd nijmy się dokoła z dobrą wolą, a znajdziemy niejedną rzecz cenną i ukochania godną [podkr. - KMM]". L. St aff, Rekonwalescencja..., op. cit., s. 61.

${ }^{31}$ Kwiatkowski teleowitalizm definiuje wprost jako „przełomowy pogląd przypisujący funkcję celu zjawisku, o którego cel pytano dotychczas - życiu”. Patrz J. K w i a tk ow s ki, Poeta paradoksu [w i d e m:] op. cit., s. 129.

32 Dodać w tym miejscu należy, iż pojęcia entelechii (entelécheia) i energii (enérgeia) posługiwano się w myśli filozoficznej synonimicznie - postępował tak chociażby św. Tomasz z Akwinu. Por. M. A. Krąpie c, Entelécheia [w:] Powszechna encyklopedia filozofii, Lublin 2002, t. 3, s. 171. 
Powrót na ,,brzeg jałowy” przyziemnej, antyidyllicznej codzienności wiąże się $\mathrm{z}$ natychmiastową zmianą tonacji w tkance metaforycznej poematu. Bezbrzeżny zachwyt tętniącym witalizmem wyspy ustępuje dawnej apatii (,,brzeżny piasek" jest tu przede wszystkim przeciwieństwem bezbrzeżności otchłannego doświadczenia), wolicjonalnej niemocy i dojmującej, bezsilnej rozpaczy:

\section{Długo płakałem! A wszystkie łzy na nic! \\ Aż wstała burza z koralowych ławic. \\ Przyszła z wichurą i krzykiem błyskawic \\ I zaśpiewała potęgą bez granic!}

Alegoryzująca chaos i destrukcję ideału nawałnica, zdająca się być zrazu elementem beznadziejnego krajobrazu rzeczywistości, jest w istocie rzeczy sublimacją gwałtownych uczuć podmiotu lirycznego, albowiem w poemacie w pejoratywnym świetle ukazywane są jedynie bezruch, bezsenność i bezczynność. Stąd też „obłąkany bóg” burzy jest adekwatem szaleństwa poetyckiego, a śpiewana przezeń carmen furiosa ma wzbudzić na powrót w świadomości podmiotu teleowitalistyczną chęć zespolenia z jednią:

\footnotetext{
I wielbiciela miała [burza] we mnie, świadku.

A żem uwielbił, osiągłem nagrodę,

Bo napędziła mi burza na wodę,

Do brzegu, szczątek rozbitego statku.
}

Nie więc obrazoburstwo ideału, lecz nadzieję niesie ze sobą burza, ofiarowując możliwość powrotu „,bez steru i wiosła” do krainy snu:

$$
\begin{aligned}
& \text { I w dal porwany huragannym prądem, } \\
& \text { W łodzi na morzu tańcząc oszalałem, } \\
& \text { Jak burza dzikim szczęściem się zaśmiałem, } \\
& \text { Bom leciał w bezkres wód za swym wylądem! }
\end{aligned}
$$

Wraz ze wznowieniem wędrówki w drugiej części poematu, jego tkankę metaforyczną poczyna przepełniać tonacja woluntarystyczno-optymistyczna ${ }^{33}$, będąca żywą emanacją wszechludzkiego pragnienia wiekuistej szczęśliwości w jednej, bodaj i najkrótszej chwili. Obietnicę utopii (nie po raz pierwszy skądinąd) niesie ze sobą żywioł wody, który - abstrahując od oczywistości sytuacji topograficznej każdej wyspy - staje się portalem pomiędzy światem realnym a nierealnym, wywołującym u wędrowca stan eudajmonistycznej harmonii. Szczęśliwość to przy tym o tyle swoista, iż wynikająca z pozostawania dążności wszelkiej w stanie potencjalnym ${ }^{34}$, czystego zachwytu perspektywą ziszczania idée fixe:

\footnotetext{
${ }^{33}$ Por. H. Pań c z y k, Ze studiów nad lirykq Staffa, Poznań 1960, s. 33.

${ }^{34}$ Patrz ibidem.
} 
Gdym tańczył z pianą, u stóp czuł głębinę

Wśród wściekłych wirów, na łodzi rozbitej,

To w dno wód spadał, to znów leciał w szczyty,

Bujał i płynął - szczęśliwy, że płynę!

[podkr. - KMM]

„Trwaj chwilo, jesteś piękna!” - oto ostatni element triadycznego układu wartości w Staffowskim uniwersum, wyrażający się w paradoksie dążenia jako celu, nadrzędnego kryterium moralności nietzscheańskiej i leitmotivu poezji Leopolda Staffa zarazem ${ }^{35}$. Świat wyspy, gwałtownej pogoni za początkiem i ucieczki przed nieuchronnym końcem, jest monistyczny w ściśle plotyńskim sensie: utrzymanie jego spoistości wymaga bowiem dokonania pełnego, jak to ujmuje Jerzy Kwiatkowski, „obrotu kosmogonicznego"36, w ramach którego wyemanowane z jedni byty afirmują ją w zgodzie z ideą wiecznego powrotu. Podobny „obrót kosmogoniczny” leży w gestii Staffowskiego podmiotu lirycznego, świadomego swej idyllicznej preegzystencji i dążącego ku niej wbrew wszelkim przeciwnościom losu.

Trzy dni tak rozkosz poiła mnie biegu

Że stokroć patrząc w twarz śmierci zdradziecką

Wśród niebezpieczeństw śmiałem się jak dziecko

I nie widziałem, żem już blisko brzegu...

W filozofii Plotyna trójnia - rozumiana jako „wnętrze jedności” (Jedni), zasady twórczej rozszczepionej wewnętrznie na trzy momenty: aktywność, bierność oraz ich koniunkcję ${ }^{37}$ - jest reprezentacją oddziaływania siły ostatniej, łączącej przeciwności i rozbijającej binarne opozycje (horacjańska concordia discors). U Junga siła ta zresztą niebezpodstawnie skojarzona jest z latencją - wprowadzenie bowiem trzeciego elementu odwołuje się do modelowego wyobrażenia rodziny, w której „,w ślad za egzystencją dwójki (ojca i matki) niemal nieuchronnie idzie trójka (dziecko)" ${ }^{38}$. Jeśli uzupełnić kontekst ten o uwagę, iż trójkąt pozbawiony wierzchołka wedle Mikołaja z Kuzy jest alchemicznym symbolem powietrza, zaś

35 Jak zauważa Jerzy Kwiatkowski, to właśnie owa dążność do wędrowania w jedności ze światem jest najgłębszą z ukazanych przez Staffa w Epitafium (Gałaź kwitnqca, 1908) tajemnic życia:

Urodziłam się kwiatem, zmarłam pośród kwiecia:

Wśród dwóch zagadek cicho przemknęła się - trzecia.

(Epitafium)

Patrz J. Kwiatk ow ski, op. cit., s. 96-97.

${ }^{36}$ Ibidem, s. 217.

${ }^{37}$ Por. J. E. Cirlot, Trójnia [w:] op. cit., s. 425.

${ }^{38}$ C. G. Jung, A Study of the Transformations and Symbolism of the Libido, University of Michigan 1957. Cyt za: J. E. Cirlot, ibidem. 
obrócony wierzchołkiem w dół ${ }^{39}$ - wody (a, nawiasem mówiąc, także analogonem serca, co dopełniałoby parantelę wyspa-kobieta), maestria Staffa w kreowaniu ewokujących nieprzebrane mnogości kontekstów metafor ujawni się w całej rozciągłości. Trop ostatni jest o tyle intrygujący, iż koegzystencja żywiołu wody i powietrza, sygnalizowana przez Leopolda Staffa wszelkimi dostępnymi dykcji lirycznej sposobami, w Wyspie zawsze wiąże się z punktami węzłowymi:

\footnotetext{
Nagle spostrzegłem: tuż, tuż, skalne wały!...

A łódź gna oślep na głazy, w rozbicie...

Skoczyłem w topiel mórz unosząc życie

A statek strzaskał się o brzeg w kawały...

Dopadłem brzegu! Wyspo! mych snów ziemio!

Raju owiany tęsknoty błękitem!

Olśnij mnie cudem, zadziwem, zachwytem,

Odkryj swe czary, co w szczęściu twem drzemią
}

W przypominającym nieco triadę egzystencjalną Schopenhauera (pożądanie $\rightarrow$ nuda $\rightarrow$ katastrofa) cyklu przeżyć podmiotu lirycznego przychodzi czas na swoistą anamnezę: powraca doń obraz „raju owianego tęsknoty błękitem” i, jak się początkowo wydaje, los uczynił zadość jego prośbie o wyspę szczęśliwą. Pewność tę zaburza jednakże rozciągająca się na cztery dalsze strofy kunsztowna hypotypoza, wyzyskująca do poetyckiego opisu wyspy - poza elementami odwołującymi się do oczywistej w tym wypadku sfery egzotyki i orientu - także elementy z porządku mitycznego i onirycznego:

Drzewa twe złote, łąki purpurowe

Groty z szafiru, piękne jak zdziwienie Słońce, którego burszty nowe lśnienie

Rzuca na szmaragd rzek cienie różowe;

Pawie, jak w tęczach chodzące ogrody,

Lwy jak pożary, co błądzą przez błonie, Jak noc rumaki, jak śnieg białe słonie

Gibkich tygrysic łagodne pochody,

Ptaki olbrzymie, od snu o nich większe, Jaszczury złote u modrej zatoki,

W traw wodospadach falujące stoki,

Mchy nad spoczynek po rozkoszy miększe.

Zielne fontanny paproci, z palm gęstwą

W potwornych ljanów usidlone ręce

Kwiaty gorące jak ciała dziewczęce

Owoce słodkie, słodsze niż szaleństwo.

[wszystkie podkr. - KMM]

${ }^{39}$ Patrz J. E. Cirlot, Trójkq̨t [w:] ibidem. 
W Staffowskiej hypotypozie teleowitalizm podmiotu litycznego poddany zostaje mityzacji, stając się wyrazem nie tyle szaleńczej, pożądliwej dążności, ile samej potrzeby transcendencji - wyspa jest już bowiem „słodsza niż szaleństwo”. Raz więc jeszcze ukazuje się ona, wciąż niby przez przydymione szkło, lecz nie jest to już dawna „,przystań błądząca”, majacząca w ,„przeźrocznej, niechwytnej otchłani” - to prawdziwie Wyspa Klejnotów (,groty z szafiru”, „bursztynowe lśnienie [słońca]”, ,szmaragd rzek”), ,piękniejsza niż zdziwienie”, wschodni analogon lapis philosophorum ${ }^{40}$. To dlatego spokojne, połyskliwe złocienie zastąpiły teraz barwy intensywne i psychodeliczne (,drzewa twe złote”, „łąki purpurowe”, „cienie różowe”), których bogactwo, wielość i ontyczną jedność symbolizuje paw (metafora ,pawie, jak w tęczach chodzące ogrody”), kojarzony skądinąd - podobnie, jak i lew - już w czasach starożytnych z ideą królewskości ${ }^{41}$ (złoto i purpura). W tym jednak kontekście ówże lew, którego skóra nadto w kulturach pierwotnych była atrybutem solarnym i który w symbolice alchemicznej określany był mianem ,ognia filozoficznego"42 (stąd i owe tajemnicze ,lwy jak pożary”), jest raczej reprezentacją gorejącego słońca, znamionującego niebezpieczną bliskość świata nieosiągalnych idei, „od snu o nich większego”. Wyczuwalne już w tym miejscu wrażenie witalistycznego nasycenia potęguje metafora ,białe jak śnieg słonie", wywołująca skojarzenie z dawną syjamską tradycją utożsamiania białego słonia z ideą kosztownej, bezużytecznej godności ${ }^{43}$, a także zwiastująca przesycenie wizja „słodszych od szaleństwa owoców” - symbolu wzmiankowanego już Schopenhauerowskiego znudzenia pożądaniem.
O snów mych bujnie rozżagwione wrzątki!
Kędyż jest marzeń mych wezbrany przepych
Pośród tych głuchych piasków i skał ślepych?
Daremnie wszystkie przebiegłem zakątki!
Pustce jałowej, bezpłodnej umarłej
Jeńcem mnie dały ślepe trafy losu!
Łódź w drzazgi poszła, a głuche niebiosy
I tonie, które pierścieniem mnie zwarły.

To nie sen już, lecz rzeczywistość. Lub... sen o śnie, okrężne samozapośredniczenie, paradoks utopii, rozwiewającej się w ulotny dym przy najlżejszym kontakcie ze światem realnym. To utopijna afazja ${ }^{44}$, zawieszenie sądu nad rzeczywistością, swoisty lęk przed odarciem marzenia z piękna poprzez ukonkretnianie tego, co wymyka się racjonalnemu osądowi. To moment, w którym, jak zauważa

${ }^{40}$ Id e m, Wyspa [w:] op. cit., s. 465.

${ }^{41}$ Paw [w:] ibidem, s. 303.

${ }^{42}$ Lew [w:] ibidem, s. 222-223.

${ }^{43}$ Por. W. Ko palińs ki, Słownik mitów i tradycji kultury, Warszawa 1985, s. 96-97.

${ }^{44} \mathrm{O}$ afazji jako „oderwaniu od rzeczy” w sceptycyzmie Pirrońskim patrz G. Reale, Myśl starożytna, przeł. E. I. Zieliński, Lublin 2003, s. 436. 
Irena Maciejewska, ,świat realny przeplata się [...] ze światem marzeń, a granice ich jak kontury na impresjonistycznych płótnach zacierają się i rozpływają"45. Staffowski homo viator, stawszy się igraszką „ślepych trafów losu”, ponownie trafia do ,pustki jałowej, bezpłodnej, umarłej”, pułapki egzystencjalnej (zwiastowały ją już ,potwornych ljanów usidlone ręce” sprzed kilku wersów) idealisty. I w tym też miejscu, w którym koniec łączy się z początkiem, po raz pierwszy pojawia się także refleksja nad smutkiem wyspiarskiego solitudo:
Nie ujrzę już ludzi, na bezmiarze
Martwym na zawsze od życia odcięty!
Ach, nie przybiją tu żadne okręty!
O, ludzkie głosy, ludzkie oczy, twarze!
Żywcem do grobu wtrącony, trup żywy
Płacząc zębami gryzłem piasek suchy...
I noc zastała mnie na męce głuchej
Wlokąc za grzywy pian morskie przypływy.

Afazja i ataraksja były, wedle Pirrona z Elidy, prekursora tzw. sceptycyzmu akademickiego, pierwszymi warunkami osiągnięcia apatii, obojętności poznawczej, niewrażliwości na bodźce zewnętrzne i ,całkowitego ogołocenia z człowieczeństwa"46. Nie była to przy tym bynajmniej, jak może się zrazu zdawać, postawa kontestatorska czy nihilistyczna; przeciwnie, w myśli Pirrona, jak referuje Giovanni Reale, owo „całkowite ogołocenie” miało nieść urzeczywistnienie „,natury tego, co boskie i dobre, od której spływa na człowieka życie jak najbardziej równe"47. Dlatego właśnie podmiot liryczny Wyspy, osiągnąwszy stan afazji i zawiesiwszy chwilowo sąd o możliwości istnienia wyspy-tajemnicy, niezdolny jest do osunięcia się w całkowitą, bezmierną pustkę: w jego uszach bowiem poczyna rozbrzmiewać - i jest to bodaj najpiękniejsza ze Staffowskich metafor nadziei - ,gędźba gwiezdna”:
A mnie zdumienie dziwem pierś zatchnęło,
Bo jęła w uszach grać mi gędźba gwiezdna!
Ogromny wstawał śpiew z morskiego bezdna!
Morze budziło się i grać zaczęło!

„Ale mam zwykłą skrzypkę, co nuci, o tem, co znikło, co już nie wróci” - pisał Staff w jednym z początkowych wierszy tomu Ptakom niebieskim ${ }^{48}$, ujmując $\mathrm{w}$ tej śsiewnej maksymie kwintesencję swej filozofii radosnego niespełnienia ${ }^{49}$.

${ }^{45}$ I. M a c i je w s ka, O poez.ji Leopolda Staffa [w:] Leopold Staff, Warszawa 1965, s. 11.

${ }^{46}$ G. Re ale, loc. cit.

47 Ibidem.

${ }^{48}$ L. Staff, Pogoda [w:] op. cit., s. 39.

49 Szerzej analizuje ten epifenomen Irena Maciejewska: „Eskapistyczne pojęcia marzenia przeciwstawionego życiu, skazanego na „niespełnienie” przybiera u Staffa biegunowo odmienny, 
Radość z doświadczania samego doświadczenia, nasycenie eudajmonizmem chwili, śnienie o śnieniu i świadomość „dialektycznej łączności świata wyobraźni, świata marzeń i tęsknot ludzkich ze światem zdarzeń" ${ }^{50}$ - oto główne dominanty filozofii Staffowskiej i spiriti moventes całej sytuacji lirycznej poematu. „Śpiew z morskiego bezdna” to poetycka repryza rozbrzmiewającego w pierwszych strofach poematu syreniego pienia, ponownie symbolizującego tu nieodpartą pokusę utopii, idealistyczny regressus ad infinitum:

Śniło [morze - KMM] o wyspie, gdzie są złote gaje,

Gdzie w rzekach płyną tęcze pawiooczne,

Gdzie zachwycenia mieszkają obłoczne

Kędy sen jawy jawą snu się staje!

Antymetabola „sen jawy jawą snu” jest kluczem do pojęcia istoty przesłania Wyspy ${ }^{51}$. Idealistyczny wymiar nadają bowiem owej krainie nie tyle konwencjonalne elementy topiki idyllicznej (,złote gaje”, „tęcze pawiooczne”, „zachwycenia obłoczne"), ile właściwa jej unikatowa moc odrealniania rzeczywistości i urealniania nierzeczywistości. Ujawniania snu-ontofanii, będącego permanentną możliwością, Heideggerowskim „bytem wyprzedzającym siebie” (sich-vorwegsein $)^{52} \mathrm{i}$ idealną preegzystencją. To dlatego akt wolicjonalny podmiotu lirycznego znajduje swe odbicie już nie w nim samym, lecz w lustrze wody:

\author{
Mym snem o wyspie grało morze $\mathrm{z}$ toni! \\ Morze też jeno śniło ją w swem leżu! \\ Na całem jego ogromnym bezbrzeżu \\ Nie było wyspy tej, lecz jest wieść o niej! \\ Wieść-wróżba, która objawienie niesie: \\ Że lśni w zaświatach wyspa-tajemnica. \\ Więc nie był złudą mój sen i tęsknica \\ Że ma ojczyznę dusza ma w bezkresie... \\ Morze! zostanę tu dla wróżb tej pieśni! \\ Wiecznie chcę słuchać o snów wyspie cudnej \\ Wieści! Nie tęsknię już z pustki bezludnej \\ Do ludzi ani do dawnej swej cieśni!
}

[wszystkie podkr. - KMM]

jasny, radosny nastrój”. Patrz I. M a c ie je w s k a, Leopold Staff - lwowski okres twórczości, Warszawa 1965, s. 215.

50 Ibidem, s. 220.

${ }^{51}$ Nieodosobnienia niniejszej interpretacji dowodzi wypowiedź Stanisława Brzozowskiego: „Poezja Staffa jest poezją czasów, które szczerymi były w marzeniu tylko - Staff w marzeniu żyje, życie usiłując wymyślać”. S. B r zo zow s ki, Kultura i życie, Warszawa 1973, s. 144, cyt. za: M. Wy k a, Leopold Staff, Warszawa 1985, s. 21.

${ }_{52}$ Kontekst Heideggerowski w poezji Staffa analizuje szerzej W. Gutowski. Por. W. G u to w s ki, Między idyllq a inicjacjq. O „Ziemi dziewiczej” Leopolda Staffa [w:] Poez.je..., op. cit., s. 168. 
Nie byt więc realny, lecz ulotna idea decyduje o zachowaniu principium individuationis, tak wobec siebie samego, jak i wobec świata. Ojczyzną błędnego żeglarza staje się sam bezkres, wieczysta obietnica celu i idealistycznej ,pp o d ró ż y w odkry c i e"53, będącej, jak diagnozuje Artur Sandauer, jednym z podstawowych założeń Staffowskiej filozofii wiecznego dążenia i wiecznego odrzucania osiągniętych celów ${ }^{54}$. Myśl owa najpełniej bodaj wyraża się właśnie w występującej w Wyspie antynomii Raju Utraconego i Raju Odzyskanego, na styku których rodzi się nadzieja na szczęście. Niemożność bowiem osiągnięcia stanu eudajmonizmu jest dla Staffa nie tyle antytezą szczęśliwości, ile neutralnym status quo, nadającym sens i kierunek mitycznemu teleowitalizmowi ${ }^{55}$. „Wieść-wróżba" z kolei jest tu jedyną widomą oznaką istnienia transcendentnego (,na całem jego [morza] ogromnym bezbrzeżu I nie było wyspy, lecz jest wieść o niej”), wykraczającego poza rzeczy nieskończone, res infinitas. Poza „gędźbą gwiezdną”, mistyczną pieśnią dźwięczącą w przestworze (tak powietrznym, jak i morskim) na podobieństwo pitagorejskiej muzyki sfer ${ }^{56}$, nie słyszy wyspiarski errabundus nic zgoła ponad głos cichy swego daimonionu, odzywający się echem w morskiej toni:

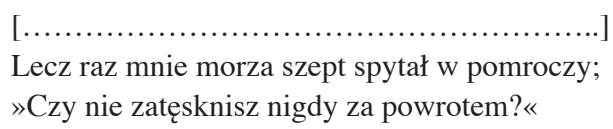

Jakże jednak świadomie rezygnować z błogiego śnienia o loco amøno, z jakże ludzkiej, naturalnej próby - cytując Herberta - ,zaczepienia wózka o gwiazdę”? Utopijna afazja przeradza się w ostatniej części poematu w ataraksję i apatię,

${ }^{53}$ Patrz L. S taff, O radosnej ojczyźnie [w:] Ptakom niebieskim, Lwów 1905, s. 213.

${ }^{54}$ Termin Artura Sandauera. Por. A. S a n d a u e r, Poeci trzech pokoleń. Staff. Tuwim, Słonimski, Iwaszkiewicz, Broniewski, Przyboś, Gałczyński, Jastrun, Warszawa 1955, s. 12.

${ }^{55}$ Mieczysław Jastrun za najpiękniejszą metaforę Staffowskiej idei nieosiągalności szczęścia (choć, by wyrazić się ściślej, jest to raczej czerpanie radości ze świadomości nieosiągalności szczęścia) uznał wiersz z cyklu Radość i smutek szczęścia i chwili (Gałq̨́ kwitnq̨a, 1908):

\footnotetext{
Między pieśnią przerwaną a zbudzonym echem,

Falą i nagą stopą, co wnet się zanurzy,

Przyjściem listu i zdjęciem pieczęci z pośpiechem,

Pomiędzy zaproszeniem i rankiem podróży,

Między wzniesioną dłonią a owocem drzew

Ś pi szczęście [podkr. - KMM]

(Radość i smutek szczęścia i chwili, V)
}

Patrz M. J a stru n, Wstęp [w:] L. S ta ff, Wybór poezji, BN I 181, Wrocław 1985. Notabene, jeśli pokusić się o uzupełnienie interpretacji Jastruna o analizowany w niniejszej pracy psychoanalityczny wątek latencji jako elementu uśpionego trójni, w pełni wówczas unaoczni się konsekwencja filozoficzna poezji Staffa.

56 Tatarkiewicz w właściwy sobie metaforyczny sposób określa ją „symfonią świata”. Por. W. Tat arkiew ic z, Historia filozofii, Lwów 1931, t. I, s. 62. 
sceptycyzm wobec świata ${ }^{57}$, połączony z brakiem refleksji nad tym, co przeszłe i brakiem oczekiwania na to, co przyszłe:

Nigdy nie ujrzę już twarzy człowieka

A wichr tu żadnej łodzi nie przywieje...

Znalazłem spokój, bom stracił nadzieję,

Nic tu nie stanie się już, nic nie czeka...

Podobnie jak przejrzyste jezioro mąci gruda gliny, tak i ideał zawsze bruka bezpośredni kontakt z rzeczywistością ${ }^{58}$, wywołującą uczucie tęsknoty za naturalnością ludzkiej niedoskonałości. Sen ulatnia się inter os atque offam ${ }^{59}$, gdy tylko ataraksję (,znalazłem spokój, bom stracił nadzieję”) i apatię (,nic tu nie stanie się już, nic nie czeka") podmiotu lirycznego zakłóca przybycie ludzi do „pustki bezludnej”:

Przeszło. - Aż raz mnie świt obudził blady
I w piasku brzeżnym ujrzałem stóp ślady
I tlące się jeszcze ognisko w popiele...
Ludzie tu byli! ludzie! Po kryjomu -
W nocy - gdy spałem!... Uniosły ich wody!
Ludzie! Kochałem ich kiedym był młody!
Ach! odpłynęli na mój brzeg do domu!

Wyzyskany w strofach tych przez Staffa topos rozpoznania (anagnorismos) w pełni wpisuje się we właściwe Wyspie reguły gry niepewnych przesłanek i ukrytych znaczeń. Jedynymi znakami bowiem ludzkiej bytności w domenie snu są „tlące się jeszcze ognisko w popiele” oraz „stóp ślady” - a zatem Peirce'owskie indeksy, semiotyczne projekcje pozbawione uobecnionych przedmiotów referencji, wątłe nici wiążące rzeczywisty byt z jego chwilowym, niepewnym sympto-

57 Patrz przyp. 43.

${ }^{58}$ Pisał Friedrich Nietzsche: „Figi padają z drzew, dobre są one i słodkie, a gdy padają, pęka na nich skóra czerwona. Jestem wichrem północnym dla dojrzałych fig!". Patrz F. Nietzs che, Tako rzecze Zaratustra, przeł. W. Berent, Warszawa 2006, s. 63.

${ }^{59}$ Kontekst ten podejmuje Staff w wierszu Gra chmur (Ścieżki polne, 1919):

Wyspy Błogosławione, tyle snom mym dłużne,

Dajcie jałmużnę!

W swym świetlanym spowiciu serce me uwięźcie!

Wznoszę dłoń... Lecz się wyspy rozwiały w mgły próżne,

Próżne jak szczęście [podkr. - KMM].

Którego lot mię ścignie, nie pochwycą pięście.

(Gra chmur, SP)

Por. również przyp. 50. 
mem $^{60}$. Nawet ten jednak wystarcza, by wygnaniec z rajskich antypodów począł tęsknić „do brzegu, do cieśni”, a nawet przyznał się przed samym sobą do czczości szaleńczej swej pogoni za mrzonką:

Morze! Nic nie ma nad wróżby twych pieśni!

Wszystko dać za nie! Dom i braci rzucić!

Lecz ludzie byli tu dziś! Mogłem wrócić!

...I zatęskniłem do brzegu, do cieśni...

$$
\text { [podkr. - KMM] }
$$

Powrót ów to domknięcie „koła kosmogonicznego”, nieuchwytny moment styku końca z początkiem ${ }^{61}$, przeszłości z przyszłością i - życia ze śmiercią:

Padłem bez zmysłów... Pamięci blask zaginął...

Snu mego głębia była czarna, głucha...

Nic dziś nie pomnę... Noc przygniotła ducha...

Możem, trup martwy, po głębinie płynął?...

Bo gdym się zbudził, otwarłem powieki:

W domu-m się ujrzał! W ciasnej izbie swojej!

Gorzko płakałem bezludnej ostoi!

... I znów zatęskniłem do wyspy dalekiej...

I przypomniałem, żem morza nie przebył,

Nie słyszał wieści... Nikt się z swego domu

Nie wyrwie, choćby po klęskę pogromu!

Jam na tej wyspie pustej nigdy nie był!

„Każdy z nas jest Odysem, co wraca do swej Itaki” ${ }^{62}$. Ulissesa ze staffowskiego poematu nie powita jednakowoż ,słodki dym ojczyzny" ${ }^{63}$, lecz płacz gorzki za „bezludną ostoją”, reminiscencja tak wiele razy już doświadczanej tęsknoty. Błądziłby przy tym ten z interpretatorów, który zapragnąłby prześledzić wnikliwie, czy podmiot liryczny śnił o śnie, czy też wybrał się w podróż, która go uśpiła,

${ }^{60}$ Por. podobne wnioski Karola Zawodzińskiego: „Cały świat poezji Staffa jest tak oderwany od rzeczywistości, a raczej daje tej rzeczywistości specjalnie spreparowaną artystyczną projekcję, jest abstrakcyjny w pewnym sensie, nawet w tym, co tej poezji stanowi tak zasadniczy element tematyczny - w krajobrazowaniu”. K. W. Zaw o d z iń s k i, Ars poetica Leopolda Staffa, „Nowiny literackie" $1948 \mathrm{nr}$ 17, s. 1.

${ }^{61}$ Motyw ten powróci w wierszu Zachód jesienny (Barwa miodu, 1936), wywołującym podobną do znanej z Wyspy dyskrepancję świat magiczny-świat doczesny:

Przeszłość jak ogród zaczarowany,

Przyszłość jak pełna owoców misa.

(Zachód jesienny, BM)

Por. M. Wyk a, op. cit., s. 14.

${ }^{62}$ L. Staff, Odys [w:] Dziewięć muz (1958).

${ }^{63}$ Ho mer, Odyseja, I 57, później także Publius Ovidius Na s o, Epist. ex Ponto, I 3, 33. 
czy znowuż śnił o podróży, podczas której usnął - podobne rozważania bowiem mogłyby być użyteczne jedynie na poziomie bezpośredniej dosłowności, nie zaś $\mathrm{w}$ interpretacyjnym kontakcie z poetycko-filozoficznym namysłem nad antropologicznym sensem wędrówki, idealizmu i tęsknoty, jakim w istocie jest Wyspa. Dramatyczna konkluzja poematu (,Jam na tej wyspie pustej nigdy nie był”) jest bowiem nie tylko iluminacją prawdy o niemożności poznania absolutnego, ostateczną demaskacją iluzji czy uświadomieniem nicości człowieka wobec ,ślepych trafów losu", ale również głęboko humanistycznym osądem o potrzebie idealizmu - i eskapizmu ${ }^{64}$. Jest wołaniem Zaratustry o wyspy szczęśliwe, imaginacją par excellence i żywym dowodem ,zbawczości ułudy”. Jest poematem o pyrrusowym zwycięstwie nad wabiącym ku wyspom szczęśliwym mitycznym teleowitalizmem i odżegnującą od utopii afazją. Jest wreszcie piękną i mądrą w pozornej swej prostocie „gędźbą gwiezdną”, uświadamiającą w nostalgicznej kodzie, iż „koło kosmogoniczne” ludzkiego żywota jest w rzeczywistości kołem błędnym, circulos vitiosus, po którym porusza się gnany ślepym szaleństwem człowiek. Błędny pielgrzym doczesności.

Krzysztof M. Maj

MYTHICAL TELEOVITALISM OR UTOPIAN APHASIA: LEOPOLD STAFF'S ISLAND

Summary

This is an attempt at outlining the philosophical and literary framework of Leopold Staff's The Island. Rarely analyzed, the poem, made distinct by its universalist tone, does invite a fresh reading, especially one going beyond the narrow contexts and procedures of literary history. This approach is premised on the potential co-existence of the differentiae specificae of Staff's poetic philosophy and the phenomena that are determined by it even though validated by a different discursive principle. Crucial to this analysis are two philosophical categories, mythical teleovitalism (a term coined by Jerzy Kwiatkowski and suited like no other to capture the specific quality of Staff's poetry,) and a utopian aphasia (ie. a critical distance towards all utopias undercut by a longing for some form of utopian projection - an attitude that can be found across a wide range of classicist poetics). It is argued that these two categories have a key role in organizing the structure of the poem which deals with the submerged tensions between an appreciative and an unapproving view of a dream about 'a mystery island'.

${ }^{64}$ Pisał sam Staff w przywoływanej już Rekonwalescencji końca wieku: „Wiek XIX nie wydał żadnej myśli ogólnoludzkiej, żadnego dążenia, które by zelektryzowało i porwało za sobą wszystkich. Brak jakiegoś jednego wielkiego ideału, [...] niezliczone hasła i programy krzyżujące się i głuszące wzajemnie rozstrzelały i różniczkowały ludzi. [...] Jednostce w trąconej w takie środowisko nie pozostawało nic innego, jak ona sama, oderwanie się od wszystkiego i zamknięcie w sobie [podkr. - KMM]". L. Staff, Rekonwalescencja..., op. cit., s. 56. 